\section{Colour of Celestine}

Soye months ago, through the good offices of Mr. B. Topley, of Messrs. Albright and IVilson, Oldbury, we obtained several specimens of celestine from near Yate, Glos. Some were colourless, others tinged with blue, whilst a few were red. The blue crystals have been observed locally to occur lining channels or 'pipes' where water has bored through the massive mineral; the particular conditions favouring the red crystals are not apparently known.

The blue colour, to which celestine owes its name, is usually attributed to traces of vivianite, which possesses deep pigmentary power ${ }^{1}$. This, however, can scarcely explain the red colour.

Doelter $^{2}$ attributed the colours of celestine and numerous other minerals to the presence of colloidal inclusions, the degree of dispersion of which would determine the colour, whilst the concentration would determine the depth of that colour. Ho suggested, further, that the blue colour of celestino might be caused by colloidal sulphur produced by reduction of some of the sulphate.

Spectrograms of our specimens showed that whilst only minute traces of iron were present, the characteristic lines of gold were well defined in the red and blue specimens, but were scarcely perceptible in the white. The gold was extracted with aqua regia, reduced with phenyl hydrazine ${ }^{3}$ and weighed on a sintered glass funnel using a microbalance. The iron was determined colorimetrically.

The results were as follows :

\begin{tabular}{|c|c|c|c|c|c|}
\hline & & \multicolumn{2}{|c|}{ Gold (p.p.m.) } & Iron & (p.p.m.) \\
\hline Colourles & cry'stal3 & . & nil* & & 19 \\
\hline Pale & ", & .. & 49 & & 4 \\
\hline D & $"$ & & $\begin{array}{l}85 \\
\text { to extract. }\end{array}$ & & 4 \\
\hline
\end{tabular}

It is noteworthy that the iron content was greatest in the colourless crystals, whilst the gold content rose with the depth of colour. When gently heated, the blue crystals became slightly pink, but the other crystals were unchanged.

We are inclined to the opinion, therefore, that the colours of our specimens are duo to colloidal gold. We should like to examine specimens from other localities but are experiencing great difficulty in obtaining them; perhaps somo readers of NATURE could help to obtain specimens.

J. Newton Friend.

Technical College, John P. Allchin.

Birmingham. Sept. 7.

"Dana, "Descriptive Mineralogy", 906 (1914). Micrs, "Mineralogy", $589(1929)$

"Doelter, "Die Farben der Mineralien" (1915).

- Vising Pozzi-Escot's method of reduction (Ann. Chim. Anal., 12, $90(1007)$ ).

\section{Vitamin $B_{1}$ and Acetate Oxidation by Bacteria}

IT is now lnown' that vitamin $B_{1}$ may be a necessary factor for the growth of bacteria. Bacteria can, however, be grown with minimal amounts of vitamin $\mathrm{B}_{1}$ and such bacteria (for example, Staphylococcus aureus) may show enhanced metabolic activities so far as the breakdown' of pyruvic acid is concerned, when the vitamin is added to suspensions of the washed cells ${ }^{2}$. If the bacteria are grown on a medium containing adequate quantities of vitamin $B_{1}$, the subsequent addition of the vitamin to the washed cells does not affect their metabolic changes.
It is evident that a study of the action of vitamin $B_{1}$ on the chemical changes brought about by vitamin $\mathrm{B}_{\mathbf{1}}$-deficient bacteria may throw new light on the mechanism of action of this vitamin.

So far, attention has been mainly concerned with the effects of vitamin $B_{1}$ on pyruvic acid and lactic acid breakdown, following the work of Peters and his colleagues on the effects of this vitamin on the metabolism of avitaminous pigeon brain.

Werkman and his colleagues ${ }^{3}$ have found that the growth and metabolism of propionic acid bacteria are affected by the presence of vitamin $B_{1}$.

We have found, using a washed suspension of propionic acid bacteria grown on a vitamin $B_{1}$ deficient medium, that the addition of the vitamin very markedly stimulates the oxidation of acetic acid.

Acetic acid is already known from the work of Stone, Wood and Werkman to act as a hydrogen donator in the presence of the resting cells of propionic acid bacteria.

A typical result illustrating the action of vitamin $B_{1}$ on acetate oxidation is shown by tho following figures, obtained with a suspension of bacteria grown on a vitamin $B_{1}$-deficient medium and incubated aerobically in a phosphate medium (in a Barcroft differential respiratory apparatus) at $37^{\circ}$ for two hours :

\begin{tabular}{|c|c|c|c|}
\hline $\begin{array}{l}\text { Substance arlded to } \\
\text { bacterial suipension }\end{array}$ & $\begin{array}{l}\mu l \text { oxygen } \\
\text { consumed }\end{array}$ & $\begin{array}{l}\text { Moxygen } \\
\text { consumed, } \\
\text { due to the } \\
\text { acctate }\end{array}$ & $\begin{array}{c}\mu \mathrm{I} \\
\text { acctate } \\
\text { utilized }\end{array}$ \\
\hline $\begin{array}{l}\text { No addition } \\
0.25 \gamma \text { vitamin } B_{1} \\
0.01 \text { II acetate } \\
0.25 \gamma \text { vitamin } B_{1}+ \\
0.01 \text { If acctate }\end{array}$ & $\begin{array}{r}19 \pi \\
245 \\
563 \\
1202\end{array}$ & $\begin{array}{l}\overline{7} \\
366 \\
957\end{array}$ & $\begin{array}{l}\overrightarrow{193} \\
486\end{array}$ \\
\hline
\end{tabular}

The following conclusions may be drawn. (1) In the presence of very small quantities of vitamin $B_{2}$ (for oxample, $0.08 \times 10^{-3} \mathrm{mgm}$. per $\mathrm{ml}$.) there is a very marked stimulation of the oxygen uptalie in the presence of acetate, though not in the absence of the added substrate. This stimulation is not due to an increase in the number of bacteria during the course of the experiment as cell counts have shown. (2) The ratio of oxygen uptake to acetate utilized is approximately $2 \cdot 0$ and this ratio appears to be independent of the addition of vitamin $B_{1}$. The ratio of $2 \cdot 0$ would be expected if completo oxidation of acetate occurred according to the following equation

$$
\mathrm{CH}_{3} \cdot \mathrm{COOH}+2 \mathrm{O}_{2}=2 \mathrm{CO}_{2}+2 \mathrm{H}_{2} \mathrm{O} \text {, }
$$

and estimations of carbon dioxido (or bicarbonate) formation have been consistent with this conclusion.

It would be a plausible view that the catalytic action of the vitamin is due to its accelerative effect on the oxidation of pyruvic acid possibly formed as an intermediate during the oxidation of acetic acid. Against this view, however, is the experimental fact that no pyruvic acid appears to accumulate when the acetate is oxidized by the bacteria in the absence of the added vitamin. Moreover, a ratio considerably less than $2 \cdot 0$ would bo expected if acetate wero oxidized in the absence of vitamin $B_{1}$ to an intermediate the further oxidation of which required the presence of the vitamin. Experiment has failed to show that traces of pyruvic acid block the aerobic oxidation of acetic acid. The inference would be that the acetic acid molecule itself, in the case at any rate of propionic acid bacteria, requires the presence of 